\title{
Valuing Humanity: Kierkegaardian Worries About Korsgaardian Transcendental Arguments
}

In his recent book on ethics, Alasdair Maclntyre writes as follows:

A good life is one in which an agent, although continuing to rank order particular and finite goods, treats none of these goods as necessary for the completion of her or his life, so leaving her or himself open to a final good beyond all such goods, as good desirable beyond all such goods. Defective lives are those in which agents either mistakenly identify some particular finite good that they have achieved or will achieve as their final good or suppose that failure or defeat in achieving such goods is a failure to achieve their final good. ${ }^{1}$

Maclntyre associates this idea with Aquinas; but it is also an idea that can be strongly associated with Kierkegaard, and his warning that we should not confuse absolute with relative goods or values or ends. Our aim in this paper is to consider whether a confusion of this sort afflicts Christine Korsgaard's well-known transcendental argument for the value of humanity, and thus whether it can be subjected to a specifically Kierkegaardian form of critique.

We will begin by outlining Korsgaard's position (in §1), then raising these Kierkegaardian concerns about her transcendental argument (in §2), before presenting a sketch of a different transcendental argument based on the alternative approach offered by Kierkegaard (in §3).

\section{Korsgaard's transcendental argument}

In her book The Sources of Normativity, and some associated writings, Korsgaard has offered an influential way of answering 'the normative question' which she takes to be modelled on Kant ${ }^{2}$ and which she sees as involving a transcendental argument. 'The normative question' arises, Korsgaard suggests, when you are 'in the position of an agent on whom morality is making a difficult claim', so that '[y]ou then ask the philosopher: must I really do this? Why

\footnotetext{
${ }^{1}$ Alasdair Maclntyre, Ethics in the Conflicts of Modernity (Cambridge: Cambridge University Press, 2016), p. 231

${ }^{2}$ How far Korsgaard's argument is genuinely a development of Kant's is of course a debated question in the literature, but one which cannot be considered further here. For some doubts on this score, see Jens Timmermann, 'Value Without Regress: Kant's Formula of Humanity Revisited', European Journal of Philosophy, 14 (2006), pp. 69-93.
} 
must I do it? And his answer is his answer to the normative question' ${ }^{3}$ In her book, Korsgaard canvasses various strategies for addressing this question, arguing that in the end what she thinks of as a Kantian approach is best, at the core of which is a transcendental argument.

The exact shape of that argument is not made entirely clear in Korsgaard's text, but the following provides a reconstruction which would seem to capture her main claims:

1. The normative question arises because we are reflective agents, who require actions to be based on what appear to us to be reasons, rather than being driven by impulses

2. For you to have a reason to $\Phi, \Phi$-ing must appear valuable to you

3. Since $\Phi$-ing is not valuable simply as such, it can appear to you that $\Phi$-ing is the rational thing to do only if it is required by some way in which you identify yourself (a practical identity)

4. You cannot regard your practical identity as making $\Phi$-ing required unless you can see some value in that practical identity

5. You cannot see any value in any particular practical identity simply as such, but can regard it as valuable only because of the contribution it makes to giving you reasons and values by which to live

6. You cannot see having a practical identity as valuable in this way unless you think your life as a rational agent who acts on reasons is valuable

7. To value life as a rational agent is to value your humanity

8. Therefore, you must value your humanity

Thus, in the manner characteristic of a transcendental argument, which aims (in Kant's famous phrase) to 'turn' the question back on the one who poses it, ${ }^{4}$ the normative question can be said to answer itself: from the very fact that it arises for us as reflective beings, it can be argued that such beings must value themselves in a way that shows us how to answer that question, insofar as morality is a reflection of the very value which we must presuppose in all our reasoning. For it fully to succeed, however, Korsgaard recognizes that she must add to the argument above, which just establishes that we must value our own humanity, but not that of

\footnotetext{
${ }^{3}$ Christine M. Korsgaard, The Sources of Normativity (Cambridge: Cambridge University Press, 1996). Hereafter referred to as SN.

${ }^{4} \mathrm{Cf}$. Immanuel Kant, The Critique of Pure Reason, B276.
} 
others, and so does not cover all that morality requires of us. To take this step, she makes appeal to Wittgensteinian considerations regarding the 'publicity of reasons', so that if the value of my humanity can provide me with a reason to act, it can likewise provide a reason to you, while conversely the value of your humanity can provide a reason to me. ${ }^{5}$

The argument sketched above may be elaborated in a little more detail as follows. The normative question itself assumes we aspire to be agents who act on reasons, since what we are asking for is what reason we have to act on morality in certain situations. But for an agent to have a reason to act, that action must appear good in some way, and thus valuable. The third premise then relies on claims that Korsgaard develops in some detail, where she rejects various forms of value realism, and thus the claim that values are to be 'discovered by intuition to be "out there" in the world'. ${ }^{6}$ As a result, nothing 'in the world' can have the kind of value that might be binding on us; rather, she argues, our obligations to act arise from our 'practical identities', which are descriptions 'under which you find your life to be worth living and your actions to be worth undertaking ${ }^{\prime}{ }^{7}$ Thus, acting in various ways becomes a requirement for us because of the way in which this action is tied to and expresses how we conceive of ourselves in this fundamental manner, so that not acting in this way would amount to a kind of selfbetrayal, a betrayal of all we hold dear. But of course, we can also reflect on our commitment to a practical identity, and what gives this value and significance; and, Korsgaard claims, our response to this reflection can be positive only if we see some value in the kind of rational agency that practical identities make possible, through giving us the kinds of reasons for action outlined above. However, this is then to be committed to valuing a fundamental aspect of our nature as human beings, namely our rational agency, and thus to valuing our own humanity a valuing which the transcendental argument sketched above shows to be required, and on the basis of which the normative question can be answered. Thus, as Korsgaard summarizes her core claim: 'If you had no normative conception of your identity, you could have no reasons for

\footnotetext{
${ }^{5}$ Cf. SN, p. 136: 'To act on a reason is already, essentially, to act on a consideration whose normative force may be shared with others'.

${ }^{6} \mathrm{SN}$, p. 112.

${ }^{7}$ SN, p. 101.
} 
action, and because your consciousness is reflective, you could not then act at all. Since you cannot act without reasons, you must value your humanity if you are to act at all'. ${ }^{8}$

Now, of course, Korsgaard's argument has been subjected to a good deal of criticism, where the general thrust of various particular objections is that Korsgaard's argument proves too little, that is, that it inadequately supports her answer to the normative question. In the following discussion, we propose to take a different approach: we will claim instead that what shows the argument to be problematic is the way it proves too much, that is, the way it implies an implausibly strong version of the claim that we must value our humanity. Accordingly, our question is this: if we endorse Korsgaard's argument, will we then be committed to valuing humanity both in ourselves and in other people in the wrong way? This issue has not been discussed, as it has been taken for granted on all sides that what we are setting out to establish is that humanity has value in broadly Kantian terms, and if the Korsgaardian argument works at all, it would seem to establish at least this much. Our worry arises, however, because the argument seems to establish more than the sort of value Kant was after, and as a result it can be said to overreach its target. It is this worry, we will now argue, that an appeal to Kierkegaard can help us see, thereby raising a new kind of problem for Korsgaard's approach.

\section{The Kierkegaardian worry}

Kierkegaard is an interesting figure to bring in here, because he introduces a distinction between two forms of value that is not often discussed in an ethical context, but which is needed for the criticism of Korsgaard's argument which we will develop.

Within ethics, the more standard distinctions are between agent-relative and agentneutral values; conditional and unconditional values; instrumental and final values; and hypothetical and categorical values. Very roughly, these distinctions are generally understood as follows: Things have agent-relative value if they only have value from the agent's own perspective and thus only have value to them personally, while things that have agent neutral value are valuable regardless of the agent's perspective, and thus of their preferences, projects and goals. Things have conditional value if they acquire their value from something else and thus have value in some contexts, while things have unconditional value in themselves, and

\footnotetext{
${ }^{8}$ SN, p. 123.
} 
thus have value irrespective of context. Things have instrumental value by serving as means to certain ends, while things have final value intrinsically rather than because of what they lead to. Lastly, things have hypothetical value insofar as they satisfy certain desires of the agent, while things have categorical value independently of any such desires. Clearly, these distinctions are closely interrelated, but what has been said should be sufficient for our purposes.

Now, when it comes to Korsgaard's project - which as we have noted is broadly Kantian in intent - her aim has largely been to establish that we have value in terms of the second side of these disjunctions: that is, to establish that we have agent-neutral, unconditional, final and categorical value. Indeed, for many working in ethics this is (perfectly understandably) taken to be precisely what it would be to succeed in any such ethical project: if we can be shown to have value in these terms, then this would seem to provide an adequate grounding for much of our moral thinking, and to justify the ways in which we think human beings (and other rational agents) should be treated. Thus, not unnaturally, Korsgaard has in her sights what might be called these 'Kantian dimensions of value', which are familiar from any ethical project that takes its inspiration from Kant. ${ }^{9}$

Seen from this perspective, Korsgaard's argument has come in from some criticism. For, it has been claimed, her approach fails properly to respect these Kantian dimensions of value, as in the end it comes too close to treating the value we place in humanity as grounded in our interests as agents, thus rendering the value agent-relative, conditional, instrumental and hypothetical. The basis for this worry lies in her claim that this value is something we must presuppose or assume if we are to be capable of being agents at all, thus seeming to base morality in the interest we take in being such agents, and the commitments we possess to the practical identities that make this possible. This, however, appears to give morality a basis in our own self-concern which will then distort the Kantian dimensions of value that her argument is meant to support. ${ }^{10}$

\footnotetext{
${ }^{9} \mathrm{Cf}$. SN, p. 125, where Korsgaard writes that what her argument is intended to show is that 'if you acknowledge the existence of any practical reasons, then you must value your humanity as an end in itself'.

${ }^{10}$ See for example Eric Watkins and William Fitzpatrick, 'O'Neill and Korsgaard on the Construction of Normativity', The Journal of Value Inquiry, 36 (2002), pp. 349-67, p. 361, and
} 
Whatever the rights and wrongs in this debate, this again will not be our focus here, and for the sake of this discussion we are prepared to allow that Korsgaard's argument does not fall short from the perspective of these Kantian dimensions of value. What we want to do instead, however, is to turn to Kierkegaard, and introduce a further distinction which has not yet appeared on the list given above, but which we think causes a different sort of trouble for Korsgaard - namely Kierkegaard's distinction between relative and absolute value.

To see that this is an extra dimension of value, and to get some sense of how it differs from the others and what Kierkegaard may have meant by it, consider the value that being a teacher might have to a person. We could ask whether the value teaching has for them is agentrelative, conditional, instrumental or hypothetical, or whether it is agent-neutral, unconditional, final or categorical, where it might be perfectly plausible to characterise it in terms of the second list. That is, we could say that being a teacher is valuable not just from their perspective; that it has this value independently of any particular context; that it not valuable just as a means to some end; and that it does not get its value by satisfying the person's desires. Likewise, we could say that the person themselves sees being a teacher this way, and so does not (for example) take a merely instrumental interest in it, or perform as a teacher in order to attain some further end like wealth or public esteem. Being a teacher, therefore, could be said to meet the Kantian dimensions of value.

However, there is also a further question we could ask: namely, does being a teacher have relative or absolute value in a person's life? In asking this question in a Kierkegaardian way, we would be asking whether being a teacher is the sine qua non for their lives to have meaning and significance to them, thereby providing them with their final or ultimate goal that they would never be rational to give up, come what may. If it could be claimed that this is indeed the case, and that being a teacher does indeed have this importance, then it would have absolute value; otherwise, it would have relative value. Likewise, if they saw it as having this importance, then they would be viewing it as having absolute value; otherwise, they would see it as having relative value.

Charles Larmore, The Autonomy of Morality (Cambridge: Cambridge University Press, 2008), p. 115. Thomas Nagel also accuses Korsgaard of offering an 'egoist answer to egoism' in his commentary on SN: see 'Universality and the Reflective Self' in SN, pp. 200-9, p. 206. Korsgaard responds to Nagel in SN pp. 246-51. 
Now, it seems perfectly plausible to claim that being a teacher has the Kantian dimensions of value, and so is of agent-neutral, unconditional, final and categorical value, while at the same time denying that it has absolute value, and so denying that it should be viewed as such by a person. For, it could be argued, while it would be wrong to treat being a teacher as of merely instrumental value, or to see its value as stemming from the individual's personal preferences (for example), it would still be a mistake to claim it has absolute value for a person, and thus that they should see it in those terms. Rather, it could be said, being a teacher is not what in the end gives their lives meaning, despite being undoubtedly important in many ways, and that therefore in certain situations they should be prepared to give it up rather than treat it as their final goal - and if this is not how they see things, they are mistaken. In Kierkegaardian terms, therefore, being a teacher might be said to have relative but not absolute value.

In addition, of course, one of Kierkegaard's key themes is that we are often misguided in how we assign values to things along this dimension, and so often give absolute value to what has only relative value, and vice versa: that is, we take the meaningfulness of our lives to depend on what in fact does not give our lives meaning, and so relate absolutely to the relative, while at the same time we give relative value to what should have absolute value. We thereby fail to relate relatively to what has relative value, and absolutely to what has absolute value. Thus, as Johannes Climacus, Kierkegaard's fictional philosopher, puts it in a well-known passage from Concluding Unscientific Postscript:

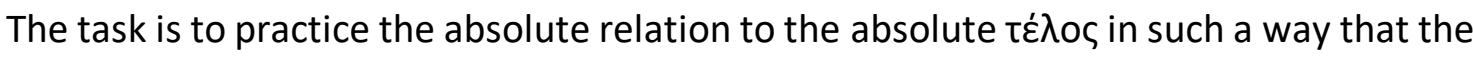
individual strives to reach this maximum: to relate himself simultaneously to his

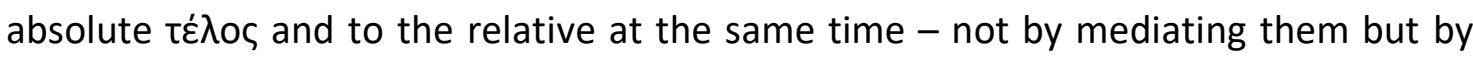

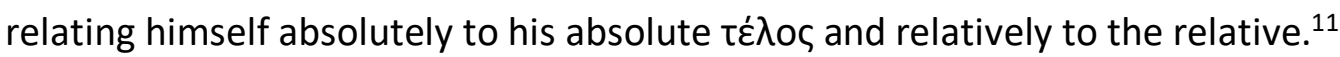

As Kierkegaard makes clear, the aim is not to replace our relations to what has relative value with relations to only what has absolute value, as this would be to withdraw too far from many

\footnotetext{
${ }^{11}$ Søren Kierkegaards Skrifter (SKS). Copenhagen: Gad, 1997- , volume VII: p. 370; Concluding Unscientific Postscript, in Kierkegaard's Writings (KW), eds. H. V. Hong and E. H. Hong, et. al., 26 volumes. Princeton, NJ: Princeton University Press, 1978-2000, vol. XII, p. 407. Kierkegaard does not use the phrase 'absolute value' here, but in the way we are using the term, to assign absolute value to an end just is to relate to it absolutely, in a way that we will go on to discuss. Unless another translation is specified, citations of Kierkegaard's works are hereon given in the form, '[English title] (SKS [volume]:[page] / KW [volume]:[page])'.
} 
perfectly worthwhile goals and relationship; rather, the aim is to keep both in play 'at the same time' and to maximize our relation to both types of value. But equally, what we should not do is try to 'mediate' between the two types, and hence confuse them, as then we will put too much value in the wrong things, and so look for a source of meaning in the wrong place. Maclntyre characterises the mistake people make here, in terms that Kierkegaard would also surely endorse:

They care about the well-being of their child, their spouse or friend, or they aspire to some extraordinary athletic or intellectual feat in such a way and to such an extent that, were that child, spouse, or friend to die or were they to fail to attain their athletic or intellectual goal, their life, so they believe, would no longer have point or purpose. They might as well be dead and there would be, they take it, no good reason for them not to commit suicide. ${ }^{12}$

Put baldly like this, what is being said may seem somehow heartless or uncaring - for, one might think, unless one were to take this kind of attitude to the death of one's spouse or child, then one could be scarcely be valuing them at all. But as we have seen, it is perfectly possible to attach relative value to something that at the same time meets the Kantian dimensions of value, and so is valued in very significant terms that differ importantly for how one values one's pastimes or sources of pleasure, for example. But where the Kierkegaardian claim is distinctive, is in saying that despite this, it can still be a mistake to find absolute rather than relative value in these people or relationships. And of course, Kierkegaard would argue that this is even clearer in other valuations we make, such as treating the fate of football teams, or job ambitions, or the ownership of certain possessions, in absolute terms - a mistake that we may nonetheless find difficult to avoid, for reasons we will go on to discuss.

In sum, then, Kierkegaard offers a perspective in which 'absolute' value is irreducible to the Kantian dimensions of value, i.e. agent-neutral, unconditional, final and categorical value. Notably, Kant does not use the terminology of absolute value in this way. In axiological contexts, Kant typically associates the term 'absolute' on the contrary with unconditional and categorical value. Thus, for example, in Groundwork he will contrast the 'absolute worth' of the

\footnotetext{
12 Maclntyre, Ethics in the Conflicts of Modernity, p. 230.
} 
good will with its having value 'on the basis of any usefulness'.$^{13}$ By contrast, a person's

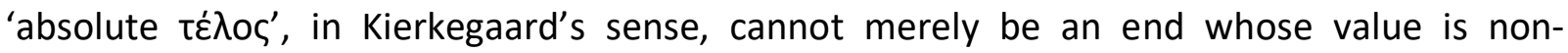
instrumental. Kierkegaard's idea is instead that of an end whose status as the standard against which a person measures the value of any other end means that its value cannot itself be measured relative to some further or higher standard. ${ }^{14}$ As we have observed, this understanding of the absolute/relative distinction allows for example for the possibility of something being, and being treated as, valuable both unconditionally and yet merely relatively.

Having articulated this Kierkegaardian dimension of value, we can now turn back to Korsgaard and ask whether she assigns relative or absolute value to humanity, and which assignment is the correct one, both in our own case and that of others? That is, even if her argument attributes the Kantian dimensions of value to humanity in the correct way, does it nonetheless fail to properly track the Kierkegaardian dimension, and so prove problematic from a Kierkegaardian perspective? To address this point, we therefore now need to ask two questions: what kind of value does Korsgaard's argument attach to humanity on the relative/absolute dimension, and does it do so correctly, or might there be reasons to think she falls into the trap Kierkegaard warns us against, of miss-assigning these values?

To answer these questions, it may be worth recalling the structure of Korsgaard's argument:

1. The normative question arises because we are reflective agents, who require actions to be based on what appear to us to be reasons, rather than being driven by impulses

2. For you to have a reason to $\Phi, \Phi$-ing must appear valuable to you

\footnotetext{
${ }^{13} \mathrm{Cf}$. Immanuel Kant, Groundwork of the Metaphysics of Morals, 4:394. It is a further and interesting question whether Kant himself recognized more dimensions of value than contemporary Kantians such as Korsgaard.

${ }^{14}$ Kierkegaard typically introduces the absolute/relative distinction as holding between types of standards against which we can measure the value of various things. Thus, he writes: 'When a person lives in such a way that he knows no criterion for life other than that of the understanding, then his whole life is relativity, working only for relative goals; he does nothing unless the understanding with some help from probability can make more or less clear the advantages and disadvantages, can answer his question "why and to what end?". It is different with the absolute' (Practice in Christianity (SKS XII: 110/KW XX: 116-17)).
} 
3. Since $\Phi$-ing is not valuable simply as such, it can appear to you that $\Phi$-ing is the rational thing to do only if it is required by some way in which you identify yourself (a practical identity)

4. You cannot regard your practical identity as making $\Phi$-ing required unless you can see some value in that practical identity

5. You cannot see any value in any particular practical identity simply as such, but can regard it as valuable only because of the contribution it makes to giving you reasons and values by which to live

6. You cannot see having a practical identity as valuable in this way unless you think your life as a rational agent who acts on reasons is valuable

7. To value life as a rational agent is to value your humanity

8. Therefore, you must value your humanity

Considering this argument from a Kierkegaardian perspective, does it involve assigning an absolute or relative value to humanity?

Now, in the way that Korsgaard herself presents her position, it is striking that she makes it sound like the value in question is absolute, precisely because she claims that unless value is given by the agent to their humanity, then nothing can have value for them: 'You must value your humanity if you are to value anything at all'. ${ }^{15}$ Moreover, she goes on to claim, unless this sort of value is attributed to humanity, life is stripped of all significance in a way that renders agency impossible: 'If you had no normative conception of your identity, you could have no reason for action, and because your consciousness is reflective, you could not then act at all. Since you cannot act without reasons and your humanity is the source of your reasons, you must value your own humanity if you are to act at all' ${ }^{16} \mathrm{It}$ would seem, then, that Korsgaard

\footnotetext{
${ }^{15}$ SN, p. 123.

${ }^{16} \mathrm{Ibid}$. In a forthcoming article, Korsgaard seeks to resolve an ambiguity in her talk of 'attributing value' to one's humanity. She now settles for a reading in which this means 'according rational beings a normative standard' rather than 'treating our rational capacities as a valuable property' ('Valuing Our Humanity', forthcoming in Respect for Persons, ed. Oliver Sensen and Richard Dean, p. 1, http://www.people.fas.harvard.edu/ korsgaar/CMK.Valuing.Our. Humanity.pdf). However, it is striking in the context of the concerns we are raising in this paper that she here reformulates her view expressly in terms of what has absolute value: 'So as I now read the argument, its point is that valuing ourselves is a presupposition of valuing anything else. As I
} 
meets the criteria for treating the value of humanity as if it is absolute, rather than relative, in claiming that being human is such that it can and should be seen as 'the source of all reasons and values' ${ }^{17}$ for the agent: 'If we do not treat our humanity as a normative identity, none of our other identities can be normative, and then we can have no reason to act at all'. ${ }^{18}$

Moreover, it is not just that, as a matter of fact, Korsgaard comes to treat humanity as having absolute value. Rather, it would seem that the success of her transcendental argument as a transcendental argument hangs on this claim. For, it is key to that argument working that she can show how any agent must value their humanity if they are to see themselves as agents at all, and it is key to that claim that if they did not they would find themselves in a world robbed of all reasons and values - for otherwise, they would not be deprived of their agency in this radical way. Thus, by the nature of the kind of argument Korsgaard offers, she is dialectically obliged to give humanity the sort of absolute value which she does. For, if agents could find reasons to act based on values, but without valuing their humanity, then it would not be necessary to value their humanity in order to have reasons to act, and the transcendental argument would collapse; but then conversely, Korsgaard must claim that the value of humanity alone gives us such reasons, which is to treat it as having absolute rather than relative value in Kierkegaardian terms.

It seems plausible, then, to suggest that once we open up this Kierkegaardian dimension of value, and consider Korsgaard's position in the light of it, that she can be said to treat humanity as having an absolute value. ${ }^{19}$ The next question that arises, therefore, is whether

would now put it, in taking the things that are good for us to be good absolutely - good in the way that makes them worthy of rational pursuit - we express the value we necessarily place upon ourselves' (ibid p. 2, Korsgaard's emphasis).

${ }^{17} \mathrm{SN}$, p. 122.

18 SN, p. 129.

${ }^{19}$ One might observe that, while her transcendental argument clearly commits Korsgaard to the idea we must value our humanity in order so much as to 'go on' at all as agents, it is less clear that she is committed to the idea that we must treat our humanity absolutely in Kierkegaard's or Maclntyre's sense, that is, as what makes one's life meaningful as a whole. For, perhaps one could regard oneself as an agent in a minimal sense, but without regarding one's life as a meaningful whole. Nonetheless, the following conditional is at any rate a clear implication of Korsgaard's argument: if we are to regard our lives as at all meaningful, we must value our humanity, for we could not regard our lives as meaningful if we did not regard 
there is anything objectionable about a position of this kind, and whether it can be deemed mistaken. This question can be asked at two levels: first, the value a person attaches to their own humanity; and, second, the value that they attach to that of other people - where, as we have seen, Korsgaard thinks she can move from former to the latter.

However, an obvious worry about the project we are pursuing here is that, given its Kierkegaardian provenance, any objection we might raise against Korsgaard at this point must rely on Kierkegaard's own conception of where absolute value resides, which is not in our humanity but in our relation to God, as it is getting this right that gives meaning and significance to our lives, and so should be seen as our ultimate purpose. Against that background, it can indeed be claimed that Korsgaard is in error, as she locates absolute value in the wrong place by finding it in the human realm without regard for the divine. Likewise, Maclntyre argues that we must make a transition from the 'enquiries of politics and ethics' into 'natural theology' if we are to do justice to what has absolute value, as 'an object of desire beyond all particular and finite goods, a good toward which desire tends insofar as it remains unsatisfied by even the most desirable of finite goods, as in good lives it does'. ${ }^{20}$ From this theological perspective, the objection to Korsgaard would then again be that she is operating at the level of the finite, which is insufficient to provide us with the kind of absolute value that she has ended up attributing to humanity.

The problem, however, is that if we take this critical path, we would seem to be relying on a theological framework that might seem to beg the question against Korsgaard, and to involve commitments that would weaken the case against her in many eyes. For, of course, to see Korsgaard as mistaken here simply because she locates absolute value in the human rather than the divine is to assume that it is in the latter, rather than in humanity, that it is to be found, and that would seem to require a commitment to a theistic picture and conception of value that Korsgaard would be within her rights simply to reject, at least without much more argument for it than can be offered here.

ourselves as agents (as then they could scarcely be our lives), and as we have seen, Korsgaard argues that valuing our humanity is a necessary condition for the latter.

${ }^{20}$ Maclntyre, Ethics in the Conflicts of Modernity, p. 315. 
However, it is perhaps not necessary to endorse Kierkegaard's full theistic account of absolute value in order to raise the worry that concerns us in this paper. For, from a Kierkegaardian perspective, it would still be enough to show Korsgaard that she is wrong, if it can be shown that she mistakenly attributes absolute value to what has relative value, not because this absolute value really lies elsewhere, but because it doesn't lie where she has located it, as this should only be given relative value. ${ }^{21}$ It may not be necessary, therefore, to endorse the positive side of Kierkegaard's position, and his claims about absolute value, still to accept the negative claim that absolute value does not reside where Korsgaard places it, as it cannot properly sustain that valuation. Can an objection of this sort be made out, both at the level of attributing absolute value to one's own humanity, and at the level of attributing it to others?

At the first level, an objection to Korsgaard's position is that, were she correct to say that humanity must be valued absolutely if we are to have any reason to act at all, then it would be hard to see how in this view it could be so much as intelligible to value one's humanity merely relatively. But this appears to be at least intelligible. It appears to be perfectly intelligible, that is, that a person might value her own rational agency merely relatively, and act accordingly with respect to that which she takes to be an absolute source and standard of value (God, the revolution, the power of love or whatever). Such an attitude is plausibly exemplified by some acts of self-sacrifice and martyrdom. ${ }^{22}$ Thus, the Kierkegaardian could argue, the difficulty with attaching absolute value to one's own humanity, in the way Korsgaard does, is that it might blind us to just this question, which can intelligibly arise for us.

\footnotetext{
${ }^{21}$ Against this, it might be said that unless something actually has absolute value, the very contrast between absolute and relative value cannot be drawn, so we must be committed to Kierkegaard's theological framework to make the point we are making here. This, however, seems to be mistaken, as the distinction can be drawn conceptually, even if nothing satisfies the concepts concerned. Some might want to insist that the distinction only makes sense at all in a Christian framework. As we shall see in the main text below, however, Kierkegaard himself gives us reasons to doubt that this is so.

22 It is true that Korsgaard distances herself from Kant's prohibition on suicide. She asks: 'Why shouldn't a human being have the standing to confer value on her own demise, as well as on anything else she desires, provided that no other duty is breached?' ('The Value of Humanity', p. 32). What Korsgaard does not concede here however is that a person could intelligibly regard her own value and 'standing' as relative to a higher standard or end.
} 
Korsgaard's response to this could be to challenge the impression of intelligibility to which we have appealed here: nothing other than rational agency could ever really take on absolute value in our eyes, as any other options could become ends at all only by being expressions of our rational agency. This is because for her, as rational agents, we can always question the value of any end, except that of rational agency. In reply, there are two points to make. Firstly, it is not clear that she would be justified in saying that the value of such other ends can always be questioned, as a possibility that arises simply from our being reflective agents. For it is plausible that, on the contrary, such reflection requires grounds for doubt or questioning. To provide such grounds, however, it is not enough merely to argue that further reflection on them is always in principle possible, since for this reflection to be rational a substantive basis is required, which Korsgaard has not articulated. ${ }^{23}$ Secondly and conversely, the reason she provides for valuing rational agency - namely that this resolves a problem we cannot escape - can seem an inadequate basis for according value to it unless we are told why this problem matters, and matters absolutely, where to establish this it is not enough just to say that it is inescapable. ${ }^{24}$

It might be replied, however, that the objection we have raised at this level can be avoided by Korsgaard without great difficulty as soon as she moves to the second level of her argument. For, it could be said, acts of self-sacrifice can be made intelligible by appeal to the absolute value of humanity in others. However, there are difficulties for Korsgaard at this level too.

The problem can be seen if we consider in more detail what it would mean to attach absolute value to humanity in others. As before, this would mean more that treating others as having the Kantian dimensions of value, and thus more than possessing agent-neutral, unconditional, final and categorical value. Rather, it would mean treating others 'as necessary for the completion of [my] life', as Maclntyre puts it. The worry, however, is that to view others in this way is to distort one's proper relation to them, making it too 'claustrophobic' and all-

\footnotetext{
${ }^{23}$ For further discussion of this issue see [reference redacted for anonymization]

${ }^{24}$ Cf. Christine M. Korsgaard, Self-Constitution: Agency, Identity, and Integrity (Oxford: Oxford University Press, 2009), pp. 23-4, where Korsgaard speaks of it being 'the human plight' that '[w]e must act, and we need reasons in order to act. And unless there are some principles with which we identify we will have no reasons to act'.
} 
encompassing. For, if I treat another person as of ultimate significance to my existence, I would seem to lose my own selfhood while encroaching too much on theirs. (Consider, for instance, the familiar phenomenon of the 'pushy parent', as exemplified recently in the film 'I, Tonya' and its portrayal of the relationship between Tonya Harding and her mother.) This does not mean, of course, that we should not be greatly affected by the lives of others and see them as having great importance to us in a huge variety of ways; but for Kierkegaard, this should still fall short of attaching absolute value to them, but it is just this kind of value which seems to be at stake in Korsgaard's argument. At this level too, therefore, there is a Kierkegaardian objection to be raised.

This line of thought in Kierkegaard notably echoes Augustine's distinction between what we use (uti) and what we should use and enjoy (frui). According to Augustine, 'it is only the eternal and unchangeable things ... that are to be enjoyed; other things are to be used so that we may attain the full enjoyment of those things' - where, by 'other things', he clearly means to include other human beings, even one's closest friends. ${ }^{25}$ On a crude reading, Augustine is here flatly contradicting the principle Kant would identify as the Formula of Humanity for the categorical imperative, i.e. he is affirming that that we should always treat finite humanity merely as means and never as an end in itself. However, on a more plausible and sympathetic reading, Augustine's thought is that to treat another mortal as one's absolute end is to refuse to acknowledge his or her finitude. As Rowan Williams puts it, by enjoying another mortal as though he or she were God, 'I take something from its actual ontological complexity and dignity, while at the same time effectively inflating that complexity and dignity to a level it cannot sustain' ${ }^{26}$ And to reiterate, we think that one might well share this worry, about the dangers of treating finite others as though their value were infinite, without sharing Augustine's or Kierkegaard's positive ontological commitments regarding 'the eternal and unchangeable things', and thus without sharing their positive theological commitments.

\footnotetext{
${ }^{25}$ Augustine, De Doctrina Christiana I.22.20, trans. R. P. H. Green, On Christian Teaching (New York: Oxford University, 1997), p. 16.

${ }^{26}$ Rowan Williams, 'Augustinian Love' in Ulrich Schmiedel and James M. Matarazzo (eds.) Dynamics of Difference: Christianity and Alterity (London: Bloomsbury, 2015), pp. 189-98. For further discussion see David Batho, 'Faith, Hope, and Love as Virtues in the Theological Tradition' http://powerlessness.essex.ac.uk/faith-hope-and-love-green-paper (C) The Ethics of Powerlessness Project 2016.
} 
It therefore appears that the Kierkegaardian critique of Korsgaard has some force. It seems that there are reasons to deny that humanity, in either ourselves or others, should be given absolute value, but that Korsgaard doesn't see this problem as she is focused on attributing the Kantian dimension of value to humanity instead. However, we have suggested, her argument overshoots this target, as it can only work by attributing absolute value to humanity, in a way that is then problematic. This then suggests a dilemma for Korsgaard: either her argument goes too far because it overshoots in this way, or she moderates her conception of the value of humanity, but then her argument fails, because she needs humanity to be the source of all value if her transcendental claims about it are to hold.

\section{A Kierkegaardian alternative}

Finally, we would like to briefly consider whether an alternative transcendental argument might be constructed that uses a more Kierkegaardian approach, which can avoid some of the difficulties we have highlighted, while at the same time bearing some resemblance to issues raised by Korsgaard's argument. This is of course a rather speculative and reconstructive exercise, as Kierkegaard himself never offered any such argument; nonetheless, an exercise of this kind may have some interest.

An argument of this sort might be laid out as follows:

1. What is finite has only relative value as an end

2. But we must take it that there is some end to which we can accord absolute value, if we are properly to relate to our finite ends as such.

3. Therefore the end to which we accord absolute value cannot be finite but must be taken to be infinite

4. To accord absolute value to an infinite end, is to see one's relation to that end as giving significance to one's life, making it meaningful and worthwhile - otherwise one won't see that life as valuable at all

5. If the relation to the infinite end gives significance to one's own life, others who stand in that same relation must also be leading lives of significance

6. So one must accord moral status to the lives of others, as having significance through their relation to the infinite end 
In what follows, we will say more about each of these premises.

The first premise is simply the Kierkegaardian claim we have discussed previously, namely, that while many things within our lives can be seen as having value, we should not give ultimate meaning and significance to our lives by attaching ourselves to those things, whether they are jobs, or possessions, or even other people. Seen aright, nothing of this sort can be sufficient to bear the normative weight we would be placing on it if we took it to be of absolute value.

Now, one response to this thought might simply be to accept it, and in a clear-eyed way see nothing in our lives except things of relative value, and thus to see those lives as lacking any relation to anything that could give them ultimate meaning or significance. For the argument against Korsgaard we discussed in the previous section, the Kierkegaardian does not need any more than this negative thought, namely that other people lack absolute value, and we would be wrong to attribute it to them. However, for the positive argument we are now considering, to get beyond this first premise, something more is required, which is what is articulated in the second premise.

What support might be given for this second premise? An argument for this claim emerges if we consider what Kierkegaard thinks is needed if indeed we are to sustain a cleareyed perspective on our finite ends. For, he evidently thinks that this is a difficult task. And the core difficulty his work articulates in this regard can be presented as a practical dilemma: either we regard our life, and its meaningfulness, as exhausted by our finite ends; or we regard our life, and its meaningfulness, as radically transcending all finite ends. On the first horn of the dilemma, by treating our finite ends as ultimate, we accord absolute value to that which can only bear the weight of relative value. In the terms introduced in The Sickness Unto Death, the self thereby 'infinitizes' its finite ends and so fails to relate appropriately to these ends as finite. Now, we can certainly try to avoid this pitfall. We can try to avoid it, for example, through practices in which we seek to detach ourselves from our finite ends so as not to let them fill our horizon. Epictetus, for instance, offers the following advice:

With regard to everything that is a source of delight to you, or is useful to you, or of which you are fond, remember to keep telling yourself what kind of a thing it is, starting with the most insignificant. If you're fond of a jug, say, 'This is a jug that I'm fond of,' and then, if it 
gets broken, you won't be upset. If you kiss your child or your wife, say to yourself that is it a human being that you're kissing; and then, if one of them should die, you won't be upset. ${ }^{27}$ Practicing the stance Epictetus commends cannot be easy. But, even were we to keep it up, we would still face the second side of the dilemma: if we detach ourselves too radically from our finite ends we will no longer be able to regard them as one's own ends. In Kierkegaard's terms, instead of infinitizing its finite ends, and in the very effort to free itself from fixated attachment to such ends, the risk now is that the self infinitizes itself and so loses its sense of itself as a practical agent for whom finite ends really matter as ends. ${ }^{28}$ Kierkegaard describes various forms such detachment can take: it may express itself for example in a confusion of oneself with God or with 'pure thought', or in a stance of emotional disengagement, or in retreat to a fantasy world in which imaginative free play is all that matters. But however exactly it manifests itself, the problem is the same: by trying to free itself from over-attachment to the finite, the self risks losing all track of itself as one for whom finite ends really matter as ends.

Kierkegaard therefore thinks that, in order properly to relate to our finite ends as such, we need somehow to avoid these twin pitfalls: being too attached to our finite ends and so failing properly to relate to them as finite ends; on the other hand, becoming too detached from our finite ends and so failing to relate to them as finite ends. These two dangers correspond to the two fundamental aspects or 'poles' of the self described by Kierkegaard's dynamic model of the self, famously introduced in Sickness as follows:

[W] hat is the self? The self is a relation which relates to itself... [I]t is not the relation but the relation's relating itself to itself. A human being is a synthesis of the infinite and the finite, of the eternal and the temporal, of freedom and necessity... Considered in this way, a human being is still not a self... The human self is ... a derived, established relation, a relation which relates to itself and in relating to itself relates to another. ${ }^{29}$

\footnotetext{
${ }^{27}$ Epictetus, Discourses, Fragments, Handbook, trans. R. Hard, ed. C. Gill (Oxford: Oxford University Press, 2014), p. 288.

28 Thus: 'the person whose feeling has become fantastic is in a way infinitized, but not in such a manner that he becomes more and more himself, for he loses himself more and more'. The Sickness Unto Death (SKS XI: 144 / KW XIX: 31)

${ }^{29}$ Ibid (SKS XI: 129-30 / KW XIX: 13-14).
} 
On this picture, the self is not a static entity, but is (so to speak) pulled across two opposed poles which draw it in two different directions: the finite, temporal and necessary on the one hand, and the infinite, eternal and free on the other. From this model of the self, it follows that properly to relate to oneself is to relate simultaneously to both these poles, the finite and the infinite. This is what it would it would mean for the self's development not to come aground by misaligning itself wholly with one side of the internal relationships that constitute its identity.

But the critical question, for Kierkegaard, is how this can be possible: that is, how can the self avoid misaligning itself wholly with its finite pole without as it were swinging to the other extreme and vice versa? And how can it avoid oscillating hopelessly between the two polarities? It is by way of an answer to this question that Sickness appeals to the idea of a 'third' through which the self can seek a way of relating appropriately to the two dimensions of its selfhood. For the (pseudonymous) author of Sickness-who assumes an uncompromisingly Christian standpoint - there can be no doubt that this 'third' is, namely, God. Accordingly, God is conceived in Sickness as the transcendent ground of the self, that in virtue of which the self is a 'derived, established relation'. By coming to see itself as living 'before God', as its transcendent source and ground, the self can come to see its life as meaningful in a new way. Thus:

This self takes on a new quality and specification in being the self that is directly before God. This self is no longer the merely human self but what, hoping not to be misinterpreted, I would call the theological self, the self directly before God. And what an infinite reality this self acquires by being conscious of being before God, by being a human self that has God as its standard! ... The child, who up to then has had only its parents' standard, becomes a self through acquiring, as an adult, the State as its standard. But what an infinite accent is laid upon the self when it acquires God as its standard! The standard for the self is always: that directly in the face of which it is a self. But this in turn is the definition of 'standard'. Just as it is only possible to add together items of one kind, so everything is qualitatively whatever it is measured by; and what is qualitatively its standard of measurement [Maalestok] is ethically its goal [Maal.] $]^{30}$

30 The Sickness Unto Death (SKS XI: 191 / trans. Alasdair Hannay (Harmondsworth: Penguin: 2004), p. 111). 
We cannot here fully explore the question of how Kierkegaard thinks 'the theological self' is able to relate in a new way to both its finite and infinite dimensions. The following schematic answer will suffice for our purposes. By seeing its life as grounded in a source of value outside itself, the self can come to see its life as transcending its finite ends. On the other hand, equally by seeing its life as grounded in a source of value outside itself, the self can come to see its life as transcending its finite ends without thereby regarding itself as its own infinite ground and so losing track of its own finitude qua agent for whom finite ends really matter. The self can therefore avoid the two forms of paralysis ('despair') into which it sinks when it one-sidedly aligns itself with either its finite or its infinite dimension.

Deploying Kierkegaard's conception of the self, we can therefore summarize the following argument for Premise 2. To the extent that it fails to relate to an infinite source of value outside itself, the self will be drawn to one of its constitutive poles at the expense of the other, of either seeing itself and its life as merely finite in a way that cuts it off from the opposite pole; or as then reacting against this, and viewing itself as wholly infinite, but then overlooking and misevaluating its finitude. George Pattison has nicely put this Kierkegaardian picture as follows: 'The Sickness Unto Death shows how the self can become itself only by virtue of a double movement between finite and infinite, temporal and eternal, so that, optimally, it learns to relate to itself in its finitude - but infinitely'. ${ }^{31}$ What is needed to keep this 'double movement' going and to prevent the self from getting 'stuck' on one pole or the other, is for it to find something else to relate to, which can enable the self to give value to itself as finite on the one hand, without doing so by trying to regard itself as its own infinite source of value on the other. Only in this way can the process of self-constitution required for genuine selfhood be prevented from grinding to a premature and unsatisfactory halt.

By this argument, then, the self must see itself as relating to what has infinite value: in order to avoid misaligning itself with either of its poles, or oscillating hopelessly between them, it must see this relation as giving meaning and significance to its life in a new way. As we have

${ }^{31}$ George Pattison, 'Løgstrup on Death, Guilt, and Existence in Kierkegaard and Heidegger', in Hans Fink and Robert Stern (eds.), What is Ethically Demanded? K. E. Løgstrup's Philosophy of Moral Life (Notre Dame: Notre Dame University Press, 2017), pp. 83-101, p. 89. 
observed, Sickness develops this idea in a particular way, with reference to God and in an expressly Christian framework. In this text-as in others that assume a Christian standpoint, such as Works of Love - the self comes to see its life as conferred with new meaning and significance by coming to see itself as 'directly before God' and through faith in Christ.

We should also observe, however, that this is a Christian specification of a core idea: the idea, that is, that the self must relate to an infinite end outside itself in order properly to relate to itself and to its finite ends as such. And we should not rule out that there may be other, non-Christian, ways to specify this core idea. In fact, Kierkegaard's work elsewhere supports the view that there are other ways to try to realize the structure in which the self relates to itself through its relation to a 'third', i.e. a source of absolute value outside of itself. Thus, Postscript distinguishes between two types of religiousness: the one Climacus calls 'Religiousness $A$ ' and associates above all with Socrates; and the one he calls 'religiousness B' and identifies with Christianity. ${ }^{32}$ As an exemplar of 'religiousness $A^{\prime}$, which need not rely on any positive claim to religious revelation, Socrates could also be said to relate to himself via a 'third': in his case, not of course to God through faith in Christ but to the idea of the Good, as the infinite source of value outside of himself. ${ }^{33}$ Notably, in Kierkegaard's view, Socrates relates to the infinite, not under any positive conception of what has absolute value, but in a purely negative way as that which is not-finite. In the view Kierkegaard developed already in his magister dissertation, Socrates' very practice of philosophy constitutes a way of trying to relate absolutely to the absolute and relatively to the relative: but, by contrast with Christianity, in a negative and ironical mode. ${ }^{34}$ On this picture, through his relentless interrogation of received

\footnotetext{
32 See SKS VII: 484ff / KW XII: $555 \mathrm{ff}$.

${ }^{33}$ In the label, 'religiousness A', Kierkegaard deploys the term 'religiousness' in a notably inclusive way. In this usage, in order to count as religious, one need not accept any positive religious doctrines whatsoever. At the heart of Kierkegaard's general conception of religiousness, as covering both types $A$ and $B$, is the idea that religious life involves relating to an infinite source of value outside oneself. We leave here for further consideration the question of how far in this connection Kierkegaard's ideas can be 'secularized'.

${ }^{34}$ In the terms of Kierkegaard's dissertation, Socrates exemplifies the standpoint of irony as 'infinite absolute negativity', where 'that by virtue of which it [sc. irony] negates is a higher something [i.e. higher than any finite value] that still is not' (SKS I: 299 / KW II: 261). For a discussion of Kierkegaard's view of Socrates see [references redacted for anonymization]
} 
forms of ethical self-understanding, Socrates relates to the Good as a kind of boundary and limit, setting into ironical relief all finite goods as such. ${ }^{35}$

Clearly, there is more to be said about Christian and non-Christian ways of conceiving of what it means to relate absolutely to the absolute and relatively to the relative. But from the point of view of the ethical argument we are reconstructing, what matters is that what confers ultimate significance on a person's life lies outside the individual herself.

The fifth step is to argue that if the individual themselves sees their relation to the infinite as giving meaning and significance to their own lives, and thus making their existence worthwhile, a similar value must be imparted to the lives of others through the relation in which they also stand to the infinite. This step might be blocked by the thought that the infinite only stands in this relation to me as an individual, and not to others; but it is hard to see how any such exceptionalism could be justified, for we have no reason to think that we are somehow privileged over others in this way. Insofar as the other person is a self like me, and insofar as any self has the structural relation to the infinite which Kierkegaard has suggested, then any self must have value in the way that this makes possible for me.

Finally, then, we reach our conclusion, whereby moral status is attached to the other person, as an individual leading a life that is meaningful and worthwhile, and thus as demanding our ethical attention, ${ }^{36}$ thereby capturing the Kantian dimensions of value belonging to other people, but without making the Korsgaardian error of attributing absolute value to them.

\footnotetext{
${ }^{35}$ As Plato gives Socrates to say: "[T]he only thing I do wherever I go is to convince each of you, younger and older, not to worry about your body or your money but first to worry about your soul, to get it to be the best it can be; saying that it is not money that makes excellence, but excellence that makes money and all other good things good for people, in their private and public lives" (Plato, Apology 29e trans. James Redfield).

${ }^{36}$ What exactly 'ethical attention' comes to here may depend on what functions as the 'third' in a person's life. Thus, there may be a contrast between the ethical implications of religiousness $A$ and $B$ in this regard, where the kind of ethical attention that follows from a Socratic view of our human equality before the Good diverges from the kind that follows from a Christian conception of our equality in God's love. Compare the contrast that is sometimes drawn between the Greek ethics of justice and respect for rational independence and, on the other hand, the Christian ethics of love and acknowledged dependence (see e.g. Alasdair Maclntyre Dependent Rational Animals (London: Duckworth, 1999)).
} 
It would seem, then, that a transcendental argument could be constructed along Kierkegaardian lines which avoids the problems identified previously with Korsgaard's approach, while leading us to an ethical conclusion. Something like this argument may be said to lie behind Kierkegaard's claim in Works of Love that it is through love of God that love of the neighbour becomes possible, as it is through relating to the infinite that we can come to see the kind of value in the other person that grounds our ethical relation to them, by seeing others as also standing in relation to this infinite:

Ultimately, love for God is the decisive factor; from this originates love for the neighbour... [T] he Christian love commandment commands loving God above all else, and then loving the neighbour. In erotic love and friendship, preferential love is the middle term; in love for the neighbour, God is the middle term. Love God above all else, then you also love the neighbour and in the neighbour every human being. Only by loving God above all else can one love the neighbour in the human being. ${ }^{37}$

By showing how love for God is necessary to a self that is to remain properly structured, and how that love then grounds a love for the neighbour, Kierkegaard can therefore offer an argument which will answer 'the normative question', without committing the Korsgaardian error of confusing absolute with relative value, as here absolute value is located where it may properly be said to belong.

\section{Conclusion}

We have argued that Kierkegaard's distinction between absolute and relative value provides the basis for a distinctive form of criticism of Korsgaard's approach to the normative question: the objection that her argument proves too much. We have suggested that this criticism can be formulated without relying on theological presuppositions, since it need appeal only to the claim that no finite thing can be of absolute value, without needing to posit anything to which absolute value is properly assigned. But we have further drawn out from Kierkegaard's work a positive alternative to Korsgaard's transcendental argument, where this argument clearly does involve a certain conception of that which has absolute value. Finally, we have suggested that, while Kierkegaard articulates this conception in expressly Christian terms, he allows that what

${ }^{37}$ Works of Love [SKS IX: 64 / KW XVI: 57-8]. 
it means to relate to an absolute source of value outside oneself admits of being specified in other ways as well. 